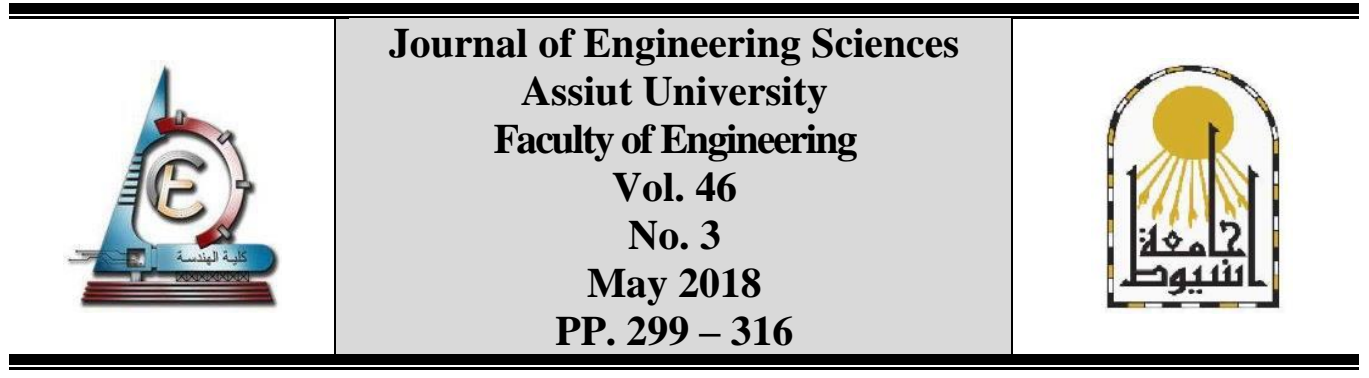

\title{
ITEMS FOR IMPROVING BOND- SLIP BEHAVIOR BETWEEN CFRP SHEETS / CEMENT BASE BONDING AGENT AND BONDING AGENT / CONCRETE INTERFACE
}

\author{
Mohamed Mahmoud Rashwan ${ }^{1}$, Atif Mohamed Abdel-Hafez ${ }^{2}$, \\ Hesham Mohamed Diab ${ }^{3}$ and Ahmed Mohamed Ali ${ }^{4}$
1, 2, 3 Civil Engineering Department, Faculty of Engineering, Assiut University
${ }^{4}$ Civil Engineer

Received 26 February 2018; Accepted 20 March 2018

\begin{abstract}
This paper concerned with the replacement of Epoxy with cement base matrixes as bonding agents for CFRP sheets. Many items were investigated to improve the bond strength and decrease slippage in strengthening system. More than 25 plain concrete prisms with low compressive strength $\left(20 \mathrm{~N} / \mathrm{mm}^{2}\right)$ were used to act as the original weak concrete members. Two main groups of cement base bonding agents were investigated in this research (Portland cement and Grout matrix's). Three main items were looked for. Item 1: mixture content; it was represented in (cement content, using silica fumes \& using short metallic fibers). Item 2: CFRP sheet modification; represented in either: a) making holes in CFRP sheets -hence the cross section area of the CFRP sheets were kept the same as all other specimens- or b) impregnate the CFRP sheets in latex-base adhesive material just before using).

Item 3: the strengthening technique; which was represented by both the bonding agent layer thickness \& the Curing pressure; (it is a pressure done with a specific value just after applying the strengthening on the concrete prism along 24 hours).

Single shear test (pull off test) was carried out to evaluate each parameter effect and the results showed that the cement-base matrixes were a very good alternative for epoxy as a bonding agent. Applying Curing pressure; almost double the bond strength and prevent the failure from occurrence in the surface interval between bonding agent / concrete interface, using latex and making holes in the CFRP sheet enhance the penetration of the bonding agent within CFRP sheet. Portland cement gives higher results than grout. Using silica fumes and even increasing the cement content; both have a negative effect on bond strength.
\end{abstract}

\section{Introduction}

Using fiber reinforced polymer (FRP) in strengthening of Reinforced Concrete (RC) structures became a very common strengthening technique. Many of researches mentioned the advantages and the disadvantages of using FRP $[1,2]$. The most important advantages which distinguish FRP are its high tensile strength, high strength-to-weight ratio and corrosion resistance. Almost all disadvantages of using FRP Strengthening technique are related to using epoxy as an adhesive material. These disadvantages may be classified as: 
1- Disadvantage related to environmental impact; represented in toxic fumes.

2- Disadvantage related to application; represented in difficulty of application at high temperature.

3- Disadvantage related to the original concrete surface; represented in needs for sufficient tensile strength of the application surface and inability of application on humid surfaces. 4- Disadvantage related to serves ability; represented in impermeability for liquids and vapors. But the major problem of using epoxy is its low glass transition temperature which may disable the whole strengthening system.

Yasmeen [3] classified the failure modes for FRP strengthening system using epoxy as adhesive as shown in Fig (1-1)). These modes of failure are in details as follow:

A) Failure which belong to strengthened member (at concrete cover), where the failure surfaces are:

1- concrete - steel separation 2- concrete failure

This type of failure may be attributed to the tensile strength of original concrete, the thicknesses of concrete cover and/or the surface preparation process; removing the cement paste or weak particles.

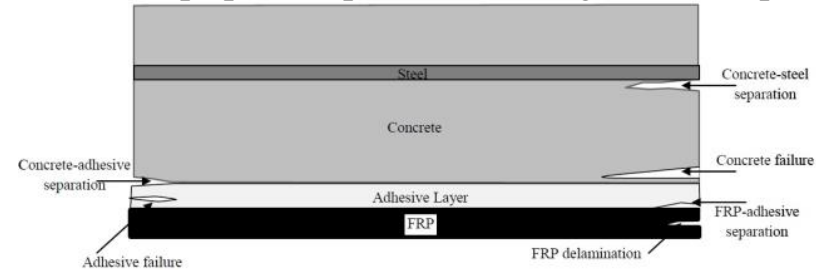

Fig (1-1): Failure modes for FRP strengthening system using epoxy as adhesive.

B) Failure of interaction between the original member and epoxy adhesive. The failure surface is: concrete-epoxy adhesive separation. The cause of this type of failure may be due to the weak cohesion between the epoxy adhesive and the original concrete.

C)Failure belonging to the strengthening system. Where the failure surfaces are:
1 - Epoxy failure
2- FRP - epoxy separation
3- FRP delamination.

The causes that may lead to this type of failure are: epoxy adhesive tensile strength and the ability of adhesive to be impregnated upon, penetrate and be cohesive with FRP sheet. These abilities of adhesive depend essentially on FRP geometry and adhesive properties. The later factor means that controlling the slippage of FRP sheet makes the strengthening system work as one unit.

Hashemi \& Al-Mahaidi [4 - 6] investigated many cement based adhesives with different components and also they studied the flexural behavior of FRP-strengthened RC beams using cement-based adhesives at both ordinary temperature and at high temperature. They tried many cement adhesive mixtures -all without any fine aggregate- but they used very fine sand (silica 200G) as filler. The mix ratios are present in Table (1-1). Table (1-2) summarized the bending test result and showed that the best results were observed when: 1- silica fume was used with CFRP (in textile form) and 2- a combination between micro cement and silica fume was used with CFRP (in sheet form). Their results showed also that using latex modified mortar decreased the failure load. But imprisoning the CFRP sheet in latex -just before applying- gave a positive effect as investigated in Amir et al study in 2012 [7]. Their results showed that the epoxy specimen's failure occurred at temperature of $462^{\circ} \mathrm{C}$ and cement adhesive failure occurred at $844^{\circ} \mathrm{C}$. The last temperature is close to the 
Ferrari et al., [8] determined the flexural toughness of many composites; they followed the recommendations prescribed by the work group (RILEM). They used many steel fiber types individually with different fiber volume percentages and also the combinations were made between fiber types with many fiber volume percentages. The mortar composites details and the Crack mouth opening displacement (CMOD) test results are summarized in Table (1-3)). They used these composites to make a transition layer to replace about $8 \mathrm{~cm}$ thickness from original RC beam. After that they applied CFRP sheets on the beam using epoxy as adhesive.

Usama et al., [9] studied two type of fiber-reinforced cementitious matrix (FRCM), PBO fabric based and carbon fabric based. These types of cementitious matrix have been used as bonding agent for PBO fabric and carbon fabric respectively. Twelve RC beams have been tasted in flexure under four point tests. The study showed that carbon FRCM strengthened beams (FRCM stiffness $=1422 \mathrm{MPa}$ ) increased by $78 \%$ and of PBO FRCM counterparts (stiffness $=605 \mathrm{MPa}$ ) by $27.5 \%$ over that of un strengthened beam.

Although the previous researches showed that the cement base bonding agents can be a good alternative for epoxy but more in depth investigation is needed. However, improving in bond capacity between FRP \& cement base bonding agents is still needed. The main objective of this study is to improve the bond capacity between CFRP sheets / cement base bonding agent and bonding agent / concrete interface. Three main items have been investigated in order to raise failure load; Item 1 (mixture content), Item 2 (CFRP sheet modification) and Item 3 (the strengthening technique). Single shear test (pull off test) has been used to evaluate each item impact on bond capacity.

\section{Experimental program}

The experimental program consisted of two main groups; Portland cement as bonding agent group I and Grout as bonding agent group II. In addition to Epoxy as bonding agent group III for comparison. For each group pre-casted concrete prisms with dimensions of $300 \mathrm{~mm}$ length and a cross section of 150 X $150 \mathrm{~mm}$ were used. These prisms were cured for 28 days before strengthening them.

\subsection{Materials}

\subsubsection{Concrete}

More than 25 plain prisms have been molded in Assiut University- Laboratory of reinforced concrete structures-in pre-prepared wooden molds; Fig. (2-1). The mixing and compacting were done mechanically. The mixtures were designed to produce $\mathrm{fcu}_{28}$ days of about $20 \mathrm{~N} / \mathrm{mm}^{2}\left(200 \mathrm{~kg} / \mathrm{cm}^{2}\right)$. This low compressive strength was chosen to simulate the real case of weak existing concrete element and/or the weak surface tensile strength. The mixing and molding was done according to ECP203 [10] recommendations. Nine standard cubes with dimensions of $150 \times 150 \times 150 \mathrm{~mm}$ were used to evaluate the compressive strength. The compression test showed that the actual average fcu 28 days $=21.5 \mathrm{~N} / \mathrm{mm}^{2}\left(215 \mathrm{~kg} / \mathrm{cm}^{2}\right)$.

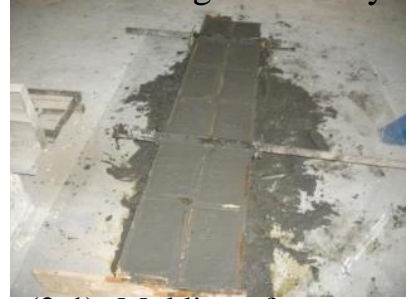

Fig (2-1): Molding of concrete prisms 


\subsubsection{Strengthening system materials}

\subsubsection{Sand}

The properties and the sieve analysis test results of the used sand are summarized in Tables (2-1) and (2-2).

\section{Table 2. 1.}

Properties of sand used for strengthening system

\begin{tabular}{|c|c|c|}
\hline $\begin{array}{c}\text { Volume weight } \\
\left(\mathrm{gm} / \mathrm{cm}^{3}\right)\end{array}$ & $\begin{array}{c}\text { Specific } \\
\text { weight }\end{array}$ & $\begin{array}{c}\text { Amount of } \\
\text { clay and fine } \\
\text { dust }\end{array}$ \\
\hline 1.72 & 2.5 & $1 \%$ \\
\hline
\end{tabular}

Table 2. 2.

Sieve analysis of sand used for strengthening system

\begin{tabular}{|c|c|c|c|c|c|c|}
\hline $\begin{array}{c}\text { Sieve size } \\
(\mathrm{mm})\end{array}$ & 5 & 2.5 & 1.25 & .63 & .31 & .16 \\
\hline $\begin{array}{c}\% \text { Passing } \\
\text { by weight }\end{array}$ & $\begin{array}{c}100 \\
\%\end{array}$ & $\begin{array}{c}99.55 \\
\%\end{array}$ & $\begin{array}{c}94.39 \\
\%\end{array}$ & $\begin{array}{c}69.11 \\
\%\end{array}$ & $\begin{array}{c}32.29 \\
\%\end{array}$ & $\begin{array}{c}3.94 \\
\%\end{array}$ \\
\hline
\end{tabular}

\subsubsection{Cement, Grout and Silica fume}

Ordinary Portland cement was used; its properties agree with ECP203 limits [10] and its properties' are presented in Table 2.3.

Grout; Sika Grout 214®Complies with ASTM C1107- according to product data sheet [11] -was used in this study. Its properties are presented in Table 2.3.

Silica fumes; Sika fume ${ }^{\circledR}$ - HR. It complies with ASTM C1240 according to user manual by silica fume association [12]. Its properties are presented in Table 2.4.

Table 2.3.

Cement and Grout properties

\begin{tabular}{|c|c|c|c|c|c|c|c|}
\hline \multirow[b]{2}{*}{ Binder } & \multicolumn{2}{|c|}{$\begin{array}{l}\text { Setting } \\
\text { time (min) }\end{array}$} & \multirow{2}{*}{$\begin{array}{l}\text { Soundness } \\
(\mathrm{mm})\end{array}$} & \multirow{2}{*}{$\begin{array}{l}\text { Specific } \\
\text { surface } \\
\text { area } \\
\mathrm{cm}^{2} / \mathrm{gm}\end{array}$} & \multirow{2}{*}{$\begin{array}{l}\text { Specific } \\
\text { gravity }\end{array}$} & \multicolumn{2}{|c|}{$\begin{array}{l}\text { Compressive } \\
\text { strength } \\
\mathrm{Kg} / \mathrm{cm}^{2}\end{array}$} \\
\hline & Initial & Final & & & & 7 days & 28 days \\
\hline $\begin{array}{c}\text { Portland } \\
\text { Cement }\end{array}$ & 90 & 285 & $3 \mathrm{~mm}$ down & 2870 & 3.150 & 290 & 420 \\
\hline Grout & 84 & 186 & $2.36 \mathrm{~mm}$ down & ---- & 2.20 & 430 & 550 \\
\hline
\end{tabular}

Table 2.4.

Silica fumes properties

\begin{tabular}{|c|c|c|}
\hline $\begin{array}{l}\text { Specific } \\
\text { gravity }\end{array}$ & $\begin{array}{l}\text { Soundness }(\mu \mathrm{m}) \\
\text { Particles nominal size }\end{array}$ & $\begin{array}{l}\text { Fineness } \\
\mathrm{cm} 2 / \mathrm{gm}\end{array}$ \\
\hline 2.2 & $1 \mu \mathrm{m}$ & $104^{*}(30 \sim 15)$ \\
\hline
\end{tabular}

\subsubsection{Steel fibers}

Sika ${ }^{\circledR}$ fiber SR 1050 is a low carbon; cold drawn steel fiber meets the requirements of ASTM A820 as Type II fiber according to product data sheet [13]. Fiber length is $50 \mathrm{~mm}$ with average aspect ratio 50 and diameter of $1 \mathrm{~mm}$. Its properties are presented in Table 2.5. And it can be seen in Fig (2-2). 


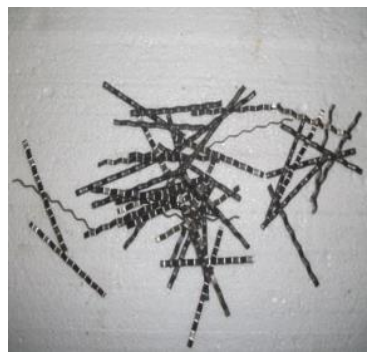

Fig (2-2): Corrugated Steel fibers

Table 2.5.

Steel fibers properties

\begin{tabular}{|l|c|c|c|l|}
\hline & $\begin{array}{c}\text { Size } \\
(\mathrm{mm})\end{array}$ & $\begin{array}{c}\text { Specific } \\
\text { gravity }\end{array}$ & $\begin{array}{c}\text { Tensile } \\
\text { strength } \\
\left(\mathrm{kg} / \mathrm{cm}^{2}\right)\end{array}$ & $\begin{array}{c}\text { Alkali, stain } \\
\text { and salt } \\
\text { resistance }\end{array}$ \\
\hline Steel fiber & $50 \times 1$ & 7.2 & 8500 & Stainless \\
\hline
\end{tabular}

\subsubsection{Plasticizers}

Addicrete PVF® by CMB ${ }^{\circ}$ was used in this study. It complies with ASTM C 494-80 Type B, F according to product data sheet [14]. Its specific gravity is 1.18 .

\section{Table 2.6.}

CFRP properties

\begin{tabular}{|c|c|c|c|c|c|c|c|}
\hline & $\begin{array}{c}\text { Fiber } \\
\text { density } \\
\mathrm{Gm} / \\
\mathrm{cm} 3\end{array}$ & $\begin{array}{c}\text { Fiber } \\
\text { modulus(2) } \\
\text { Kg / cm2 }\end{array}$ & $\begin{array}{c}\text { Fiber } \\
\text { weight } \\
\mathrm{gm} / \mathrm{m} 2\end{array}$ & $\begin{array}{c}\text { Thickness } \\
(1) \\
\mathrm{mm}\end{array}$ & $\begin{array}{c}\text { Tensile } \\
\text { strength(2) } \\
\mathrm{t} / \mathrm{cm} 2\end{array}$ & $\begin{array}{c}\text { Tensile } \\
\text { elongation } \\
\%\end{array}$ & $\begin{array}{c}\text { Tensile force } \\
\text { at .6\% strain } \\
/ \mathrm{m} \text { width }\end{array}$ \\
\hline CF130 & 1.7 & $240 * 104$ & 300 & .165 & 38 & 1.55 & 21.1 \\
\hline
\end{tabular}

\subsubsection{CFRP sheet}

MBRAC® CF 130 by BASF@ was used. It is a uni-direction carbon fiber fabric. Its properties according product data sheet [15] are presented in Table 2.6.

\subsubsection{Resins}

MBRAC® saturant by BASFC is a two component epoxy resin was used in this study. It has tensile strength > $17 \mathrm{MPa}$ and Flexural strength > $35 \mathrm{MPa}$ as mentioned in product data sheet [16].

\subsubsection{Addibond 65}

Addibond $65 \AA$ by $\mathrm{CMB} \odot$ was used in this study. It's a latex base adhesive material usually used to connect the old and new concrete. It's Complies with ASTM C 631 according to product data sheet [17]. It's only used for impregnate the CFRP fabric just before making C40-AD65 specimens.

\subsection{Strengthening technique}

After the prisms have been cured for 28 days the following steps have been followed:

\subsubsection{Surface preparation}

For Cement and grout; surfaces of the specimens were roughened mechanically using a steel brush (Fig 2.3 (a) left side). - For Epoxy specimens the surface was leveled 
mechanically using emery paper (Fig 2.3 (a) right side). Loose and weak particles were removed and the surface was washed by pure water. Fig ( $2.3 \mathrm{~b}$ and c) show epoxy specimens surface after preparation and Cement, grout Specimens' surface after roughening.

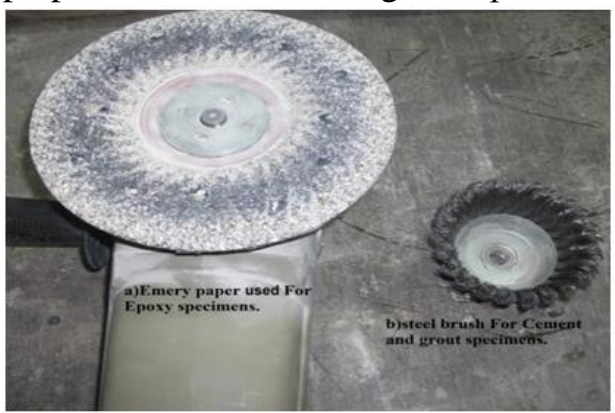

Fig $(2-3(a))$
Fig (2-3(a, b \& c ) ). Surface preparation.

Fig (2-3(a)): Emery paper \& steel brush.

Fig (2-3(b)): Epoxy specimens surface after preparation.

Fig (2-3(c)): Cement, grout Specimens' surface after roughening.

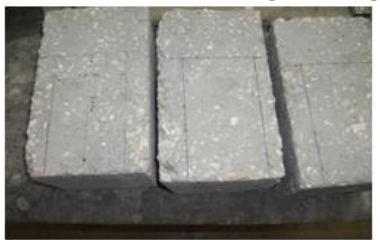

Fig (2-3(b))

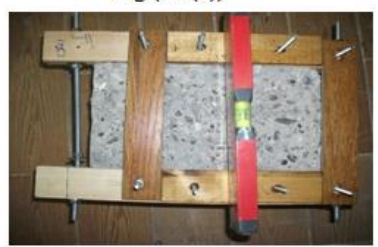

\subsubsection{Applying strengthening}

For Cement and grout specimens the concrete surface was moistened and then the first bonding agent layer was applied with specific thickness covering the total prism width. Then the first ply of CFRP sheet having a specific width was laminated with a spatula in the wet bonding agent matrix. The work continued by the same way until the last CFRP ply which was covered with bonding agent layer having a specific thickness. The interval bonding agent layers thicknesses' and details of CFRP ply's will be shown later in this research. For Epoxy specimens the concrete surface was totally dried and the wet lay-up technique was used.

\subsubsection{Curing pressures \& the post strengthening curing}

The curing pressure is a pressure done with a specific value just after applying the strengthening on the concrete prism along 24 hours. The pressure has been done by a hydraulic jack with a value of $0.165 \mathrm{~kg} / \mathrm{cm}^{2}$ for some specimens denoted with $\mathrm{p}$. For other specimens the curing pressure value was $0.2475 \mathrm{~kg} / \mathrm{cm}^{2}$ by increase of $50 \%$. The later specimens denoted with $1.5 \mathrm{p}$. Fig (2.4) shows the curing pressure process. After Strengthening and the pressure released, the strengthened specimens were cured for 28 days by immersion in pure water. The slight pressure has been done for all specimens except Epoxy specimens and C40-s.f-0p specimen. The post strengthening curing was done for all specimens.

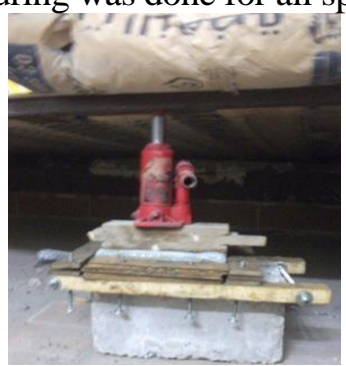

Fig (2-4): Pressure done using a hydraulic jack.

\subsection{Specimens \& bonding agent mixes details}

\subsubsection{Mix proportion}

The experimental program consisted of three main groups; Portland cement as a bonding agent group I and Grout as a bonding agent group II. In addition to Epoxy as a 
bonding agent group III for comparison as mentioned before. The cement \& grout mix proportion are presented in Table 2.7.

Table 2.7.

Bonding agent mix proportion

\begin{tabular}{|c|c|c|c|c|c|c|c|}
\hline group & $\begin{array}{c}\text { Mix } \\
\text { number }\end{array}$ & $\begin{array}{c}\text { Binder } \\
\left(\mathbf{k g} / \mathbf{m}^{3}\right)\end{array}$ & $\begin{array}{c}\text { Silica Fume } \\
\left(\mathbf{k g} / \mathbf{m}^{3}\right)\end{array}$ & $\begin{array}{c}\text { Sand } \\
\left(\mathbf{k g} / \mathbf{m}^{3}\right)\end{array}$ & $\begin{array}{c}\text { Steel fiber } \\
\left(\mathbf{k g} / \mathbf{m}^{3}\right)\end{array}$ & $\begin{array}{c}\text { Plasticizer } \\
\left(\text { litter/ } \mathbf{m}^{\mathbf{3}}\right)\end{array}$ & $\begin{array}{c}\text { Water } \\
\left(\mathbf{l i t t e r} / \mathbf{m}^{3}\right)\end{array}$ \\
\hline \multirow{3}{*}{$\begin{array}{c}\text { Cement } \\
\text { Mix }\end{array}$} & $\mathrm{C} 1$ & 400 & 0 & 1632.5 & 0 & 16 & 204 \\
\cline { 2 - 8 } & $\mathrm{C} 1 \mathrm{c}$ & 456.75 & 0 & 1587.5 & 0 & 16 & 204 \\
\cline { 2 - 8 } & $\mathrm{C} 2$ & 400 & 40 & 1587.5 & 0 & 16 & 204 \\
\cline { 2 - 8 } Grout Mix & $\mathrm{G} 1$ & 400 & 40 & 1552.77 & 100 & 16 & 204 \\
\cline { 2 - 8 } & $\mathrm{G} 2$ & 1000 & 0 & 880.25 & 0 & 0 & 193.33 \\
\hline
\end{tabular}

In both Portland cement admixtures and grout admixtures the proportion between filler materials amount to binder amount by volume will be constant for all designed admixtures; In order to keep $\left(\mathrm{V}_{\text {binder }} / \mathrm{V}_{\text {filler materials })}=\right.$ constant value the steel fiber volume will be subtracted from sand volume and silica fume volume will be subtracted from cement volume.

\subsubsection{Specimens details}

Table (2.8) shows specimens coding, a short descriptions for each specimen and the parameter measured by each specimen. Specimens dimensions are shown in Fig (2-5(a, b \&c)). For C40-AD65- (p, 1.5p) specimens the CFRP sheet had been immersioned in a Latex base adhesive material (Addibond -65®) just before using.

For C40-H-(p,1.5p) the CFRP sheet was modified by making holes using a rounded cutter with a diameter of $1.9 \mathrm{~cm}$ as shown in Fig (2-6(a)).The continuous fiber - with in rectangular borders Fig (2-6 (b)) - cross section area calculated to be the same as other specimens. These calculations are as follow:-

2 layers $\times$ [width of each layer - (holes number $\times$ hole diameter)]

$2 \times[10.7 \mathrm{~cm}-(3 \times 1.9 \mathrm{~cm})]=10 \mathrm{~cm}$ (as other specimens)

Referring for Table 2.8; all samples have the same amount of longitudinal CFRP texture.

Specimens are identified by using notations that refer to mix type, mix contents, modification done on CFRP sheet and the value of curing pressure ; where as (C \& G) stand for ordinary Portland cement and grout. The number beside $\mathrm{C}$ litter refers to cement content. Notations (AD 65, H and Th): AD 65 for immersioning CFRP sheet in Addibond $65 \circledR, \underline{\mathrm{H}}$ for modifying the CFRP sheet by making holes and $\underline{\mathrm{Th}}$ for changing the bonding agent layer thickness. (S.f and st.f) refer to silica fumes and steel fiber. (0p, p and 1.5p) refer to: no curing pressure, pressure of $0.165 \mathrm{~kg} / \mathrm{cm}^{2}$ and $0.2475 \mathrm{~kg} / \mathrm{cm}^{2}$ respectively. 
Ahmed Mohamed Ali et al., Items for improving bond-slip behavior between CFRP

Table 2. 8 .

Portland cements and grouts Specimens coding \&descriptions

\begin{tabular}{|c|c|c|c|c|c|}
\hline & $\begin{array}{l}\text { Mix } \\
\text { code }\end{array}$ & Numbers \& description of CFRP layers & $\begin{array}{l}\text { Single shear test } \\
\text { Specimens co ding }\end{array}$ & \multicolumn{2}{|c|}{ Parameter } \\
\hline \multirow{2}{*}{1} & \multirow[b]{2}{*}{$\mathrm{C} 1$} & \multirow{2}{*}{1 layer longitudinal direction } & $\mathrm{C} 40-1.5 \mathrm{p}$ & \multirow{2}{*}{\multicolumn{2}{|c|}{ control }} \\
\hline & & & $\mathrm{C} 40-\mathrm{p}$ & & \\
\hline 2 & $\mathrm{C} 1 \mathrm{c}$ & 1 layer longitudinal direction & $\mathrm{C} 45.6-1.5 \mathrm{p}$ & \multicolumn{2}{|c|}{ Cement content impact } \\
\hline \multirow[b]{2}{*}{3} & \multirow[b]{2}{*}{$\mathrm{C} 1$} & \multirow{2}{*}{$\begin{array}{l}1 \text { layer, longitudinal direction impregnated in } \mathrm{AD} \\
65\end{array}$} & C40-AD65-1.5p & \multirow{2}{*}{\multicolumn{2}{|c|}{$\begin{array}{l}\text { ADDIBOND } 65 \\
\text { impact }\end{array}$}} \\
\hline & & & $\mathrm{C} 40-\mathrm{AD} 65-\mathrm{p}$ & & \\
\hline \multirow[b]{2}{*}{4} & \multirow[b]{2}{*}{$\mathrm{C} 1$} & \multirow[b]{2}{*}{2 layers, longitudinal direction modified with holes } & C40-H-1.5p & \multirow{2}{*}{\multicolumn{2}{|c|}{ Holes impact }} \\
\hline & & & C40-H-p & & \\
\hline \multirow[b]{2}{*}{5} & \multirow[b]{2}{*}{$\mathrm{C} 2$} & \multirow[b]{2}{*}{1 layer, longitudinal direction } & C40-s.f-1.5p & \multirow{2}{*}{\multicolumn{2}{|c|}{ Silica fume impact }} \\
\hline & & & & & \\
\hline 6 & $\mathrm{C} 2$ & 1 layer, longitudinal direction & C40-s.f-0p & $\begin{array}{r}\text { Withou } \\
\text { im }\end{array}$ & $\begin{array}{l}\text { Pressure } \\
\text { pact }\end{array}$ \\
\hline 7 & $\mathrm{C} 2$ & 1 layer, longitudinal direction & C 40 -s.f-th- $1.5 p$ & $\begin{array}{r}\text { Bonding la } \\
\text { im }\end{array}$ & $\begin{array}{l}\text { yer thickness } \\
\text { pact }\end{array}$ \\
\hline \multirow[b]{2}{*}{8} & \multirow[b]{2}{*}{$\mathrm{C} 3$} & \multirow[b]{2}{*}{1 layer, longitudinal direction } & C40-s.f-st.f - $1.5 p$ & \multirow{2}{*}{\multicolumn{2}{|c|}{ Steel fiber impact }} \\
\hline & & & C40-s.f-st.f -p & & \\
\hline \multirow{2}{*}{9} & \multirow{2}{*}{ G1 } & \multirow{2}{*}{1 layer, longitudinal direction } & G-1.5p & \multirow{2}{*}{ control } & \multirow{3}{*}{$\begin{array}{c}\text { Comparing } \\
\text { with } \\
\text { Portland } \\
\text { cement }\end{array}$} \\
\hline & & & G-p & & \\
\hline 10 & G2 & 1 layer, longitudinal direction & $\mathrm{G}-\mathrm{st} . \mathrm{f}-1.5 \mathrm{p}$ & $\begin{array}{c}\text { Steel fiber } \\
\text { impact }\end{array}$ & \\
\hline
\end{tabular}
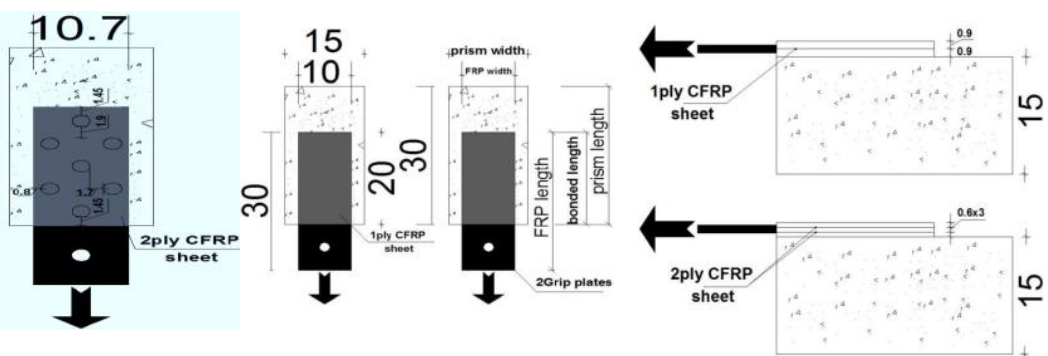

Fig (2 -5(a)): C40-H-(p, 1.5p)

Fig (2-5(b)): Dimensions for all specimens

Fig (2-5(c)): Bonding agent layer thickness except C40-H-(p, 1.5p)
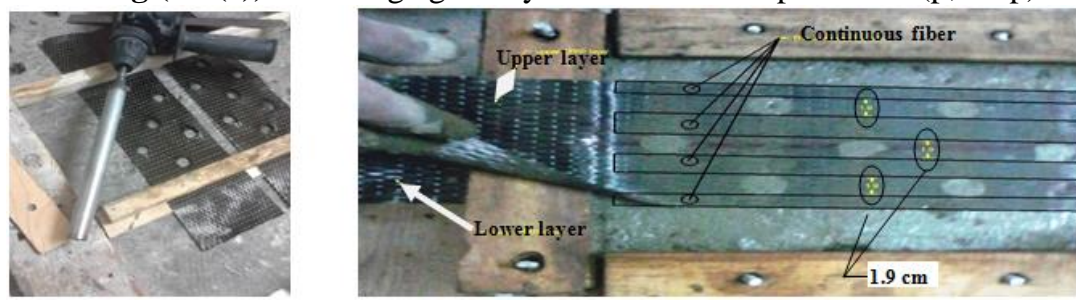

Fig (2-6(a)): Fiber modification. $\quad$ Fig (2-6(b)): Continuous fiber cumulative width.

\subsection{Test setup and instrumentation}

Single shear test (pull off test) was carried out, based on HB3052008 [18] 
The load applied horizontally by a hydraulic jack at a rate of about $600 \mathrm{kgf} / \mathrm{min}$ and it kept in the same plan with CFRP. The out of plane loading have been avoided. The displacements were measured at two points $(A \& B)$. Point $A$ is the point which was located at the soffit of the prism at the loaded side and point B was located at the far end of the concrete prism in order to make sure that the concrete prism doesn't dislocated from its position and if any; then the displacement at B will be subtracted from displacement at A.

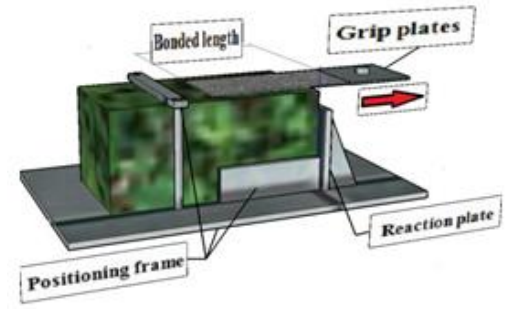

Fig (2-7(a)): Schematic view of test set up

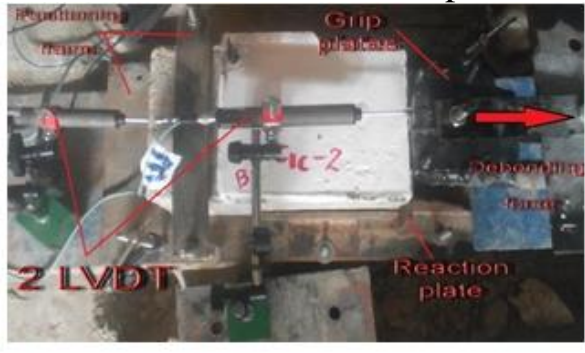

Fig (2-7(b)): Pull off test

\section{Results and Discussion}

Table 3.1 shows the summary of results for all test specimens. Columns 2 and 4 list the ultimate shear load for each specimen and the efficiency of modification which had been done on each specimen. The efficiency was measured in regard to epoxy specimen and calculated by dividing ultimate shear load for each specimen on ultimate shear load for epoxy specimen $(\mathrm{E})$.

Table 3.1.

Summary of results for all test specimens

\begin{tabular}{|c|c|c|c|c|}
\hline Specimen ID & $\begin{array}{c}\text { Ultimate Shear } \\
\text { load(KN) }\end{array}$ & $\begin{array}{c}\text { Failure } \\
\text { mode }\end{array}$ & Efficiency & Notes \\
\hline $\mathrm{E}$ & 20.52 & & 1 & \\
\hline C40 -1.5p & 29.07 & $1^{(1)}$ & 1.417 & \\
\hline C40 -p & 25.46 & $2^{(2)}$ & 1.241 & \\
\hline C45.6-1.5p & 13.11 & 1 & .639 & \\
\hline C40-AD65-1.5p & 37.43 & 1 & 1.824 & \\
\hline C40-AD65-p & 29.45 & 1 & 1.435 & \\
\hline C40-H-1.5p & 38.00 & 1 & 1.852 & \\
\hline C40-H-p & 24.51 & 2 & 1.194 & \\
\hline C40-s.f-1.5p & 26.03 & 2 & 1.268 & \\
\hline C40-s.f-p & 23.37 & 2 & 1.138 & LVDT data lost \\
\hline C40-s.f-0p & 14.25 & 1 & .694 & LVDT data lost \\
\hline C40-s.f-th-1.5p & 10.83 & 1 & .528 & LVDT data lost \\
\hline C40-s.f- st.f -1.5p & 31.73 & 1 & 1.546 & \\
\hline C40-s.f- st.f $-p$ & 22.99 & 2 & 1.12 & \\
\hline G-1.5p & 14.06 & 1 & .685 & \\
\hline G-p & 11.02 & 1 & .537 & LVDT data lost \\
\hline G -st.f-1.5p & 34.20 & 2 & 1.667 & \\
\hline
\end{tabular}


(1) Failure mode 1 refers for the failure happened with full separation of CFRP sheet as shown in Fig (3-9).

(2) Failure mode 2 refers for the failure happened with extensive slippage of the fiber within the two layers of the bonding agents as shown in Fig (3-10).

3.1. Effect of bonding agent mixture components, FRP sheet modification and using a Latex base adhesive material on ultimate shear load

Fig (3.1) shows the ultimate shear load for those specimens which had been subjected to curing pressure of $0.2475 \mathrm{~kg} / \mathrm{cm}^{2}$ compared to epoxy specimen.

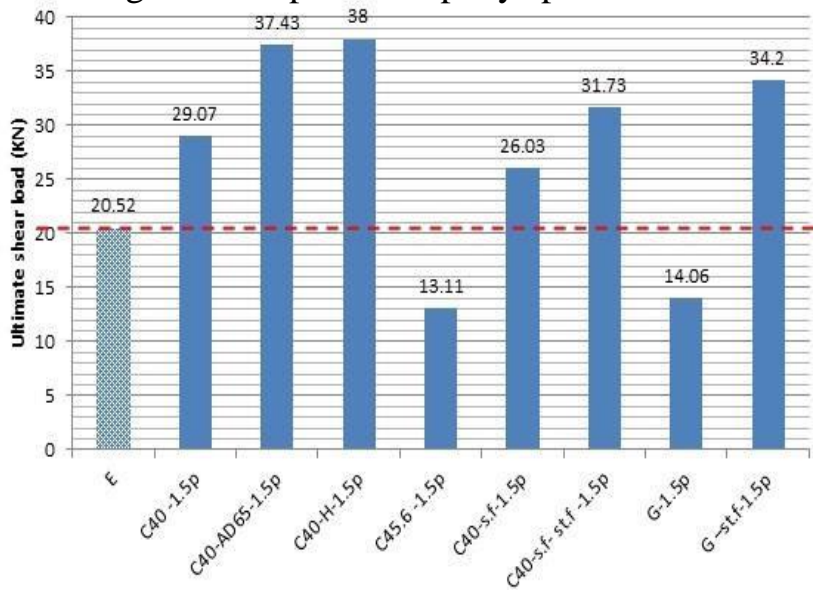

Fig (3-1): ultimate shear load for each specimen

\subsubsection{Effect of cement content}

Comparison between ( $\mathrm{C} 40-1.5 \mathrm{p})$ and (C45.6 -1.5p) showed that the increasing in the cement content by $14 \%$ decreases the ultimate shear load by $54.9 \%$; that's probably because the bonding agent became more brittle.

Hence $(\mathrm{C} 40-1.5 \mathrm{p}) \max$ load $=1.417(\mathrm{E})$

and $(\mathrm{C} 45.6-1.5 \mathrm{p})=.639(\mathrm{E})$.

\subsubsection{Effect of silica fumes}

Although (C40-s.f-1.5p) gives higher ultimate shear load than (E) by $26.8 \%$, but on comparing (C40 -1.5p) with (C40-s.f-1.5p) it is clear that the silica fumes has a negative effect on the max shear load. For the previous two points (3.1.1 and 3.1.2) the reason of the reduction happened in the max shear load, probably because the bonding agent became more brittle and with less strain ability which lead to increasing the gape in the strain computability between the FRP and the bonding agent.

\subsubsection{Effect of adding steel fibers in Portland cement bonding agent}

According to (C40-s.f- st.f -1.5p) result, the addition of steel fiber raises the ultimate shear load to be higher than (C40-s.f-1.5p) and (C40 -1.5p) by about $21.9 \%$ and $9.15 \%$ respectively.

\subsubsection{Effect of using a Latex base adhesive material}

(C40-AD65-1.5p) gave an ultimate shear load which was higher than (C40 -1.5p) by $28.76 \%$.

\subsubsection{Effect of FRP sheet modification}

(C40-H-1.5p) gave ultimate shear load higher than (C40 -1.5p) by $30.72 \%$. 


\subsubsection{Effect of using Grout instead of Portland cement}

Using grout gave almost the same negative effect on ultimate shear load as increasing cement content affect.

\subsubsection{Effect of adding steel fibers in grout bonding agent}

Although the plain grout gave (G-1.5p) ultimate shear load lower than (E) by about 50 $\%$ but when steel fiber had been added the ultimate shear load of ( $\mathrm{G}-$ st.f-1.5p) increased by about $143 \%$ compared with (G-1.5p).

\subsection{Effect of curing pressure value and bonding layer thickness on ultimate shear load}

Fig (3.2) shows the ultimate shear load for those specimens which had subjected to curing pressures of $0.2475 \mathrm{~kg} / \mathrm{cm}^{2}, 0.165 \mathrm{~kg} / \mathrm{cm}^{2}$ and zero $\mathrm{kg} / \mathrm{cm}^{2}$ with bonding layer thickness of $18 \mathrm{~mm}$ and $6 \mathrm{~mm}$ compared to epoxy specimen.

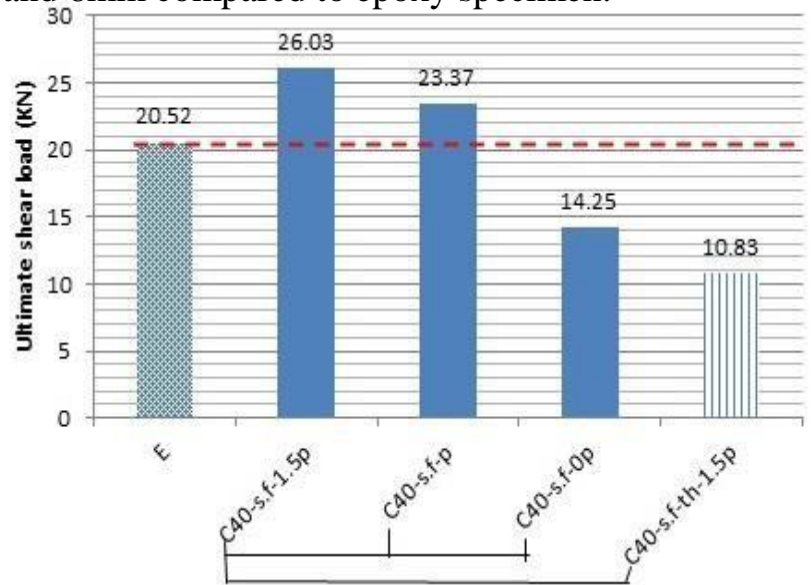

Fig (3-2):.Effect of curing pressures and bonding layer thickness on ultimate shear load

\subsubsection{Effect of bonding layer thickness on ultimate shear load:}

As seen in Fig (3.2), by comparing C40-s.f-1.5p with C40-s.f-th-1.5p it is come clear that reducing the bonding agent thickness from $18 \mathrm{~mm}$ to $6 \mathrm{~mm}$-reduction of about $33 \%$ the ultimate shear load was found to be reduced by about $60 \%$.

\subsubsection{Effect of Curing pressure value on ultimate shear load}

Fig (3.2) shows clearly that affecting by the curing pressure on the strengthened specimens until final setting occurs for the bonding agent have a great effect on ultimate shear load. This effect is bigger enough to raise the ultimate shear load from lower than epoxy specimen (E) to be higher than it. Also the gains in the ultimate shear load depend on increasing the value of the curing pressure for each bonding agent mixture individually. Fig (3.4) shows the effect of curing pressure value on ultimate shear load for each mixture and Fig (3.5) shows the effect of increasing curing pressure values by $50 \%$ on ultimate shear load for each specimen as (\%). Also the effect of the curing pressure can be seen clearly in Fig (3-3) which shows a specimen after the shear test carried out and the markers of CFRP sheet appears clearly in the bonding agent. 


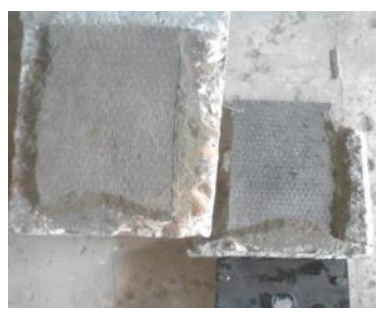

Fig(3-3): Effect of Curing pressures (CFRP sheet marked deeply in bonding agent)
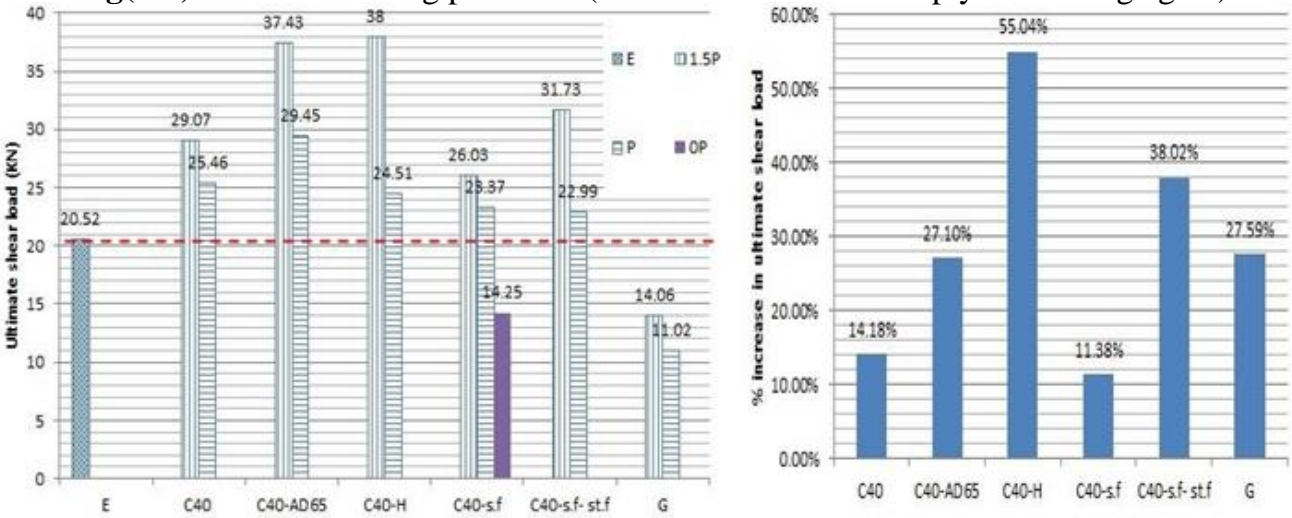

Fig (3-4): Effect of curing pressures value on

Fig (3-5): Effect of increasing fresh pressures ultimate shear load by $50 \%$ on ultimate shear load for each specimen

\subsection{Effect of bonding agent mixture components on (shear load-slip) relation.}

Fig. (3-6) shows the relation between the shear load and the slippage for different bonding agent mixtures. All specimens in this figure had been subjected to Curing pressure of $0.2475 \mathrm{~kg} / \mathrm{cm}^{2}$. Adding silica fumes made the relation became semi linear\& less strain ability. Increasing cement content gave an upward curvy line. C40- s.f- st.f $-1.5 p$ take almost an average behavior between C40-s.f-1.5p and C40 -1.5p. The grout specimen $\mathrm{G}-$ st.f-1.5p gave a relation similar to C40-s.f- st.f -1.5 p but more ductile.

Fig. (3-7) shows the effect of FRP sheet modification and using a latex base adhesive material on shear load-slip relation. C40-AD65-1.5p gave almost the same results of C40 $1.5 \mathrm{p}$ but the ultimate shear stress was bigger than $\mathrm{C} 40-1.5 \mathrm{p}$. $\mathrm{C} 40-\mathrm{H}-1.5 \mathrm{p}$ gave more brittle behavior comparing with $\mathrm{C} 40-1.5 \mathrm{p}$.

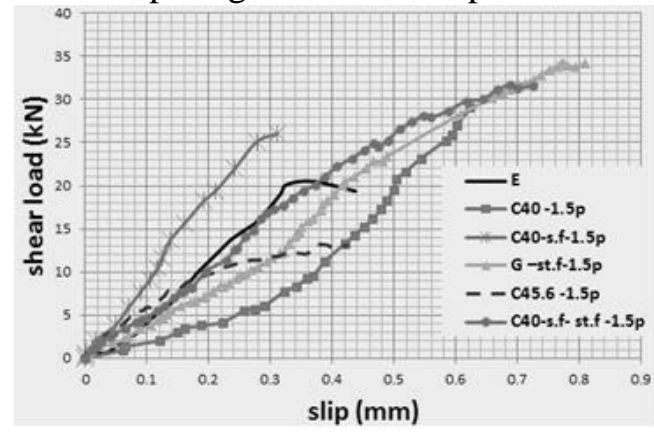

Fig (3-6): Effect of bonding agent mixture components on (shear load-slip) relation

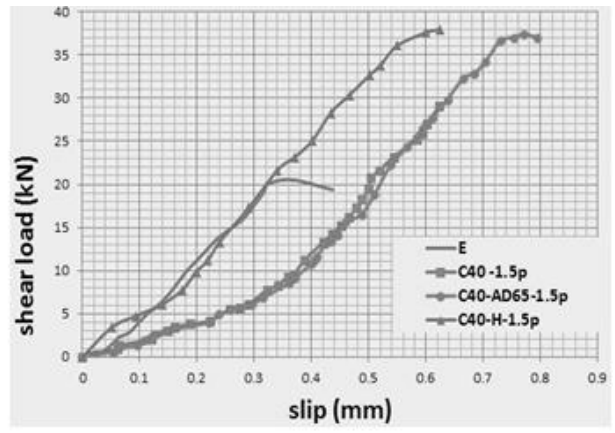

Fig (3-7): Effect of FRP sheet modification and using a Latex base adhesive material on (shear load-slip) relation 


\subsection{Effect of curing pressure value on (shear load-slip) relation}

Figs (3-8(a, b, c and d) show the impact of raising the Curing pressure value by $50 \%$ on shear load-slip relation that's for the specimens mentioned in the figures. For (C40-H-p, $1.5 \mathrm{p})$ and (C40-s.f-st.f-p, 1.5p) the raising of Curing pressure value didn't have a noticed effect on the shape of the relationship. But for (C40-p, 1.5p) and (C40-AD65-p, 1.5p) the raising of curing pressure value change the shape of (shear load-slip) relation.

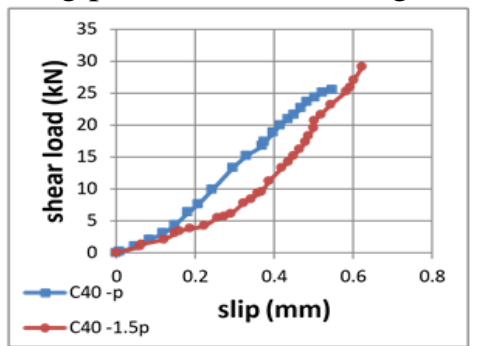

Fig (3-8(a): shear load versus slip for (C40-p, 1.5p)

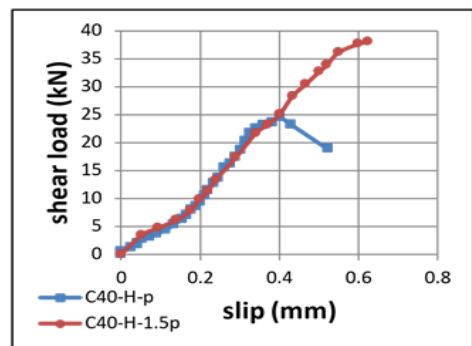

Fig (3-8(c): shear load versus slip for (C40-H-p, 1.5p)

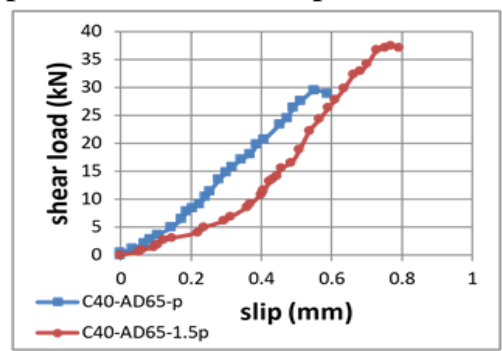

Fig (3-8(b): shear load versus slip for (C40-AD65-p, 1.5p)

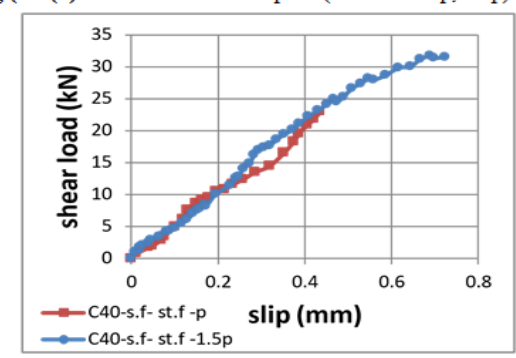

Fig (3-8(d): shear load versus slip for (C40-s.f-st.f-p, 1.5p)

\subsection{Modes of failure \& cracks patterns}

Table (3-1) summarized the modes of failure with the ultimate shear load in columns 3 $\& 2$ respectively. For cement based bonding agent two main failure modes were observed.

Mode 1: major crack occurred in the surface interval between the upper bonding layer and the lower bonding layer - the surface of CFRP sheet - started from the loaded side and propagated toward the other side. And at the same time cracks observed started and propagated like the major crack at the surface of the upper bonding layer. The load dropped suddenly with a high sound and the full separation occurred at the surface of the major crack or sudden extensive slippage happened at the failure moment.

Mode 2: this mode was similar to the previous one but the cracks were shorter and less in numbers and no separation occurred. The failure occurred by extensive slippage of the fiber within the two layers of the bonding agents. The extensive slippage happened in this mode of failure, occurred earlier than that happened in mode 1

Epoxy specimens failure mode: the failure occurred in the surface interval between the concrete and the resin as shown in Fig (3-11) 

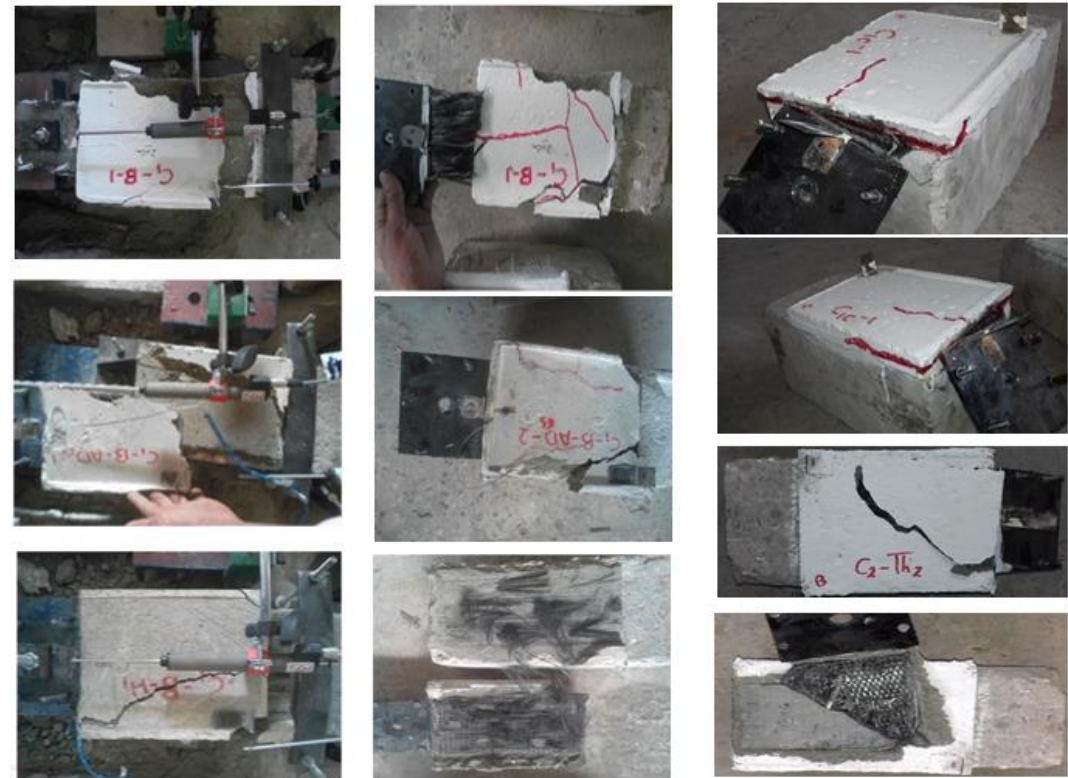

Fig (3-9): Failure mode 1.
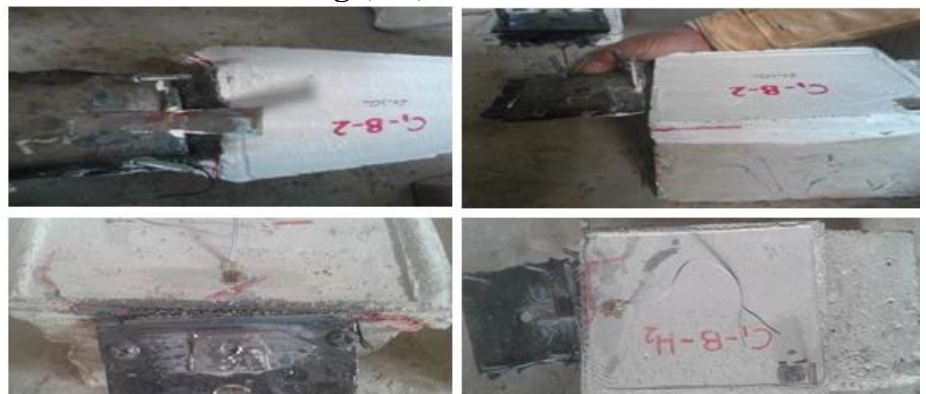

Fig (3-10): Failure mode 2.
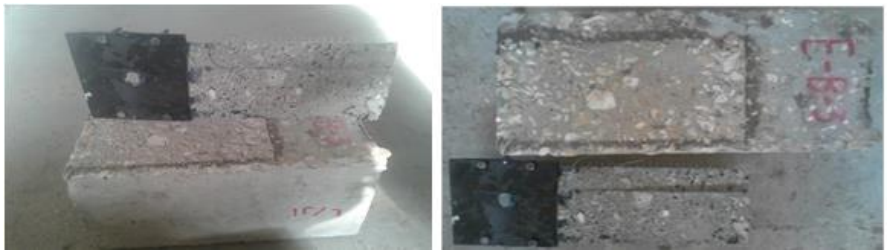

Fig (3-11): Epoxy specimen's failure

\section{Conclusion}

- This study proved that the Curing pressure value have a great impact on ultimate direct shear load. Increasing the Curing pressure by $50 \%$ increased the ultimate direct shear load by $55 \%$ for some specimens .Not only the Curing pressure enhance the penetration of the mortar within the CFRP sheet but also delayed the separation of strengthening system from the original concrete surface. However the Curing pressure must be distributed uniformly all over the strengthened area.

- Impregnating the CFRP sheets in a Latex base adhesive material just before using, clearly raises the ultimate direct shear load. That's probably because the latex adhesive enhances the penetration of the mortar within all filaments of the CFRP sheet. 
- Making holes gave highest ultimate direct shear load; when the Curing pressure $1.5 \mathrm{p}$ has been used. The holes increase the contact area between the bonding agent layers which made the bonding agent layer work as one unit.

- Increasing the cement content from $400 \mathrm{~kg} / \mathrm{m}^{3}$ to $456 \mathrm{~kg} / \mathrm{m}^{3}$ or using the silica fumes, both decreased the ultimate direct shear load. That's may be because the increasing of cement or using the silica fumes make the bonding agent became more brittle, which increases the gap in the strain incompatibility between the CFRP sheet and the bonding agent.

- Using the short corrugated steel fibers is not preferable to use, although the steel fibers gave a little increase in the ultimate direct shear load but it's hard to mix and hard in application on the beam.

- The ordinary cement is more suitable to use as a bonding agent than the grout. That's may be because the grout shrink less than the ordinary cement.

- Decreasing the bonding agent thickness from about $2 \mathrm{~cm}$ to $1 \mathrm{~cm}$; decreases the ultimate direct shear load from $26.03 \mathrm{kN}$ to $10.83 \mathrm{kN}$ (comparing between specimens C40-s.fth-1.5p \& C40-s.f-1.5p). Hence the bonding agent thickness has to be enough to resist the tension \& shear forces before transferring these forces to the concrete member. We advise the bonding agent thickness not to be less than $2 \mathrm{~cm}$.

\section{REFERENCES}

[1] S. Babaeidarabad, G. Loreto, and A. Nanni (2014): "Flexural strengthening of RCbeams with an externally bonded fabric-reinforced cementitious matrix", Journal of Composites for Construction. vol. 18, no. 5, 2014.

[2] Diab, H. (2015): "Efficiency of cement based bonding agent for FRP sheets versus Epoxy", Proc. International Conference on Advances in Structural and Geotechnical Engineering, (ICASGE 2015), Egypt.

[3] Yasmeen Taleb Obaidat, (2011): "Structural retrofitting of concrete beams using FRPDe-bonding Issues", PhD thesis, Lund University, Sweden, October 2011.

[4] Hashemi S., R. Al-Mahaidi, (2008): Cement Based Bonding Material for FRP”, Proc. 11th Intl. Inorganic-Based Fiber Composites Conference, Madrid - Spain.

[5] Hashemi S., R. Al-Mahaidi (2012): "Experimental and finite element analysis of flexural behavior of FRP strengthened RC beams using cement-based adhesives", Journal of Construction and Building Materials, Elsevier, Vol. 26(2012):268-273.

[6] Hashemi S., R. Al-Mahaidi (2012): "Flexural performance of CFRP textile-retrofitted RC beams using cement based adhesives at high temperature", Journal of Construction and Building Materials, Elsevier, Vol. 28(2012):791-797.

[7] Amir Si Larbi, Amen Agbossou, Patrice Hamelin (2012): "Experimental and numerical investigations about Textile-Reinforced Concrete and hybrid solutions for repairing and/or strengthening reinforced concrete beams", Accepted Manuscript to appear in Journal of Composite Structures, Elsevier,(2012), http://dx.doi.org/10.1016/j.compstruct.2012.12.005.

[8] V. J. Ferrari, J. B. De Hanai (2012): "Flexural strengthening of reinforced concrete beams with carbon fibers reinforced polymer (CFRP) sheet bonded to a transition layer of high performance cement-based composite adhesives", IBRACON structures and material Journal Volume 5, Number 5 (October 2012) p. 596-626 • ISSN 1983-4195.

[9] Usama A., Kshitij C., Muhammad S., Ahmed El Refai (2016): "Effectiveness of FRCM System in strengthening Reinforced Concrete Beams", Proc. Fourth International 
Ahmed Mohamed Ali et al., Items for improving bond-slip behavior between CFRP

Conference on Sustainable Construction Materials And Technologies, http://www.claisse.info/proceeding.htm

[10] ESS for cement ESS 4756-1 -Egyptian Code of Practice for Design and Construction of Concrete Structures, Housing and Building Research Center (HBRC), Ministry of Housing, Utilities and Urban Planning, Cairo, Egypt, 2007.

[11] Sika Grout 214® product data sheet, www.sika.com.eg •

[12] Silica fumes user manual, www.silicafume.org •

[13] Sika ${ }^{\circledR}$ fiber SR 1050 product data sheet, www.sika.com.eg •

[14] Addicrete PVF® product data sheet, www.cmbegypt.com .

[15] MBRAC® CF 130 product data sheet, www.basf-cc.com.eg .

[16] MBRAC@ saturant epoxy resin product data sheet, www.basf-cc.com.eg •

[17] Addibond 65 product data sheet, www.cmbegypt.com .

[18] HB 305 (2008): Design handbook for RC structures retrofitted with FRP and metal plates: beams and slabs. 2008, Standards Australia: 476, Sydney, NSW 2001, and Australia. p. 68. 


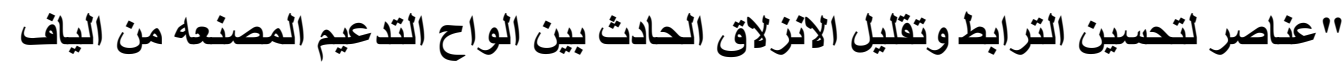

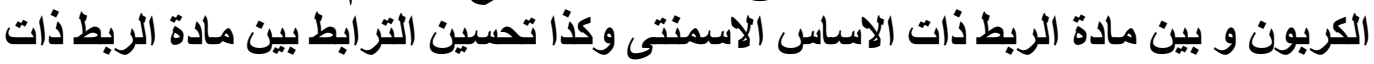
الاساس الاسمنتى والعناصر الخرسانيه المقواهين الأنئ

الملخص العربى

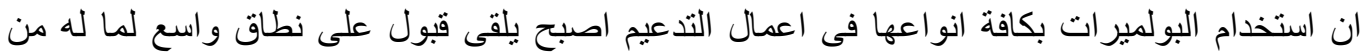

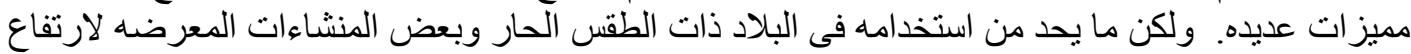

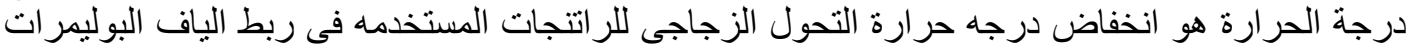

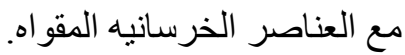

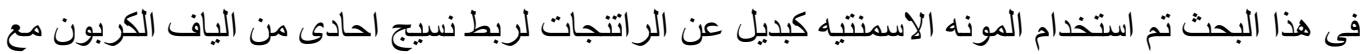

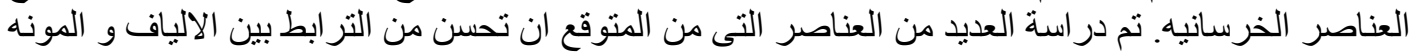

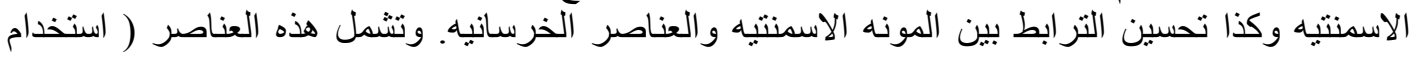

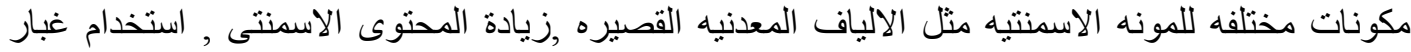

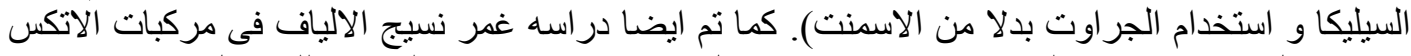

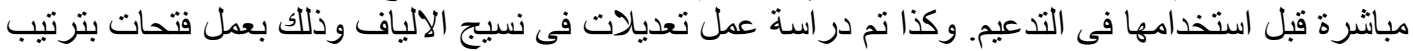

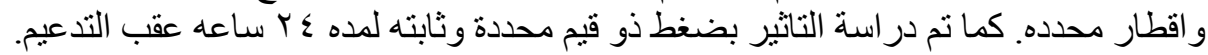

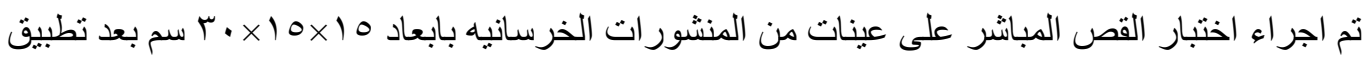

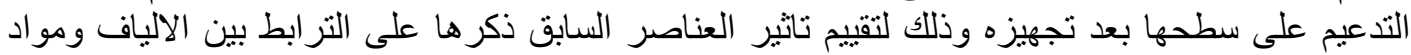

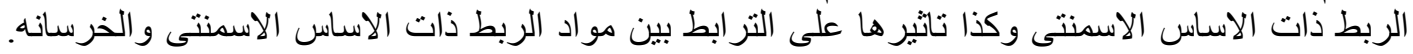

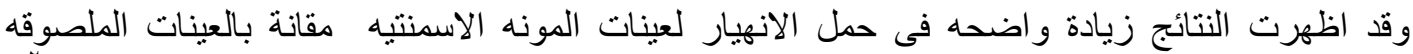

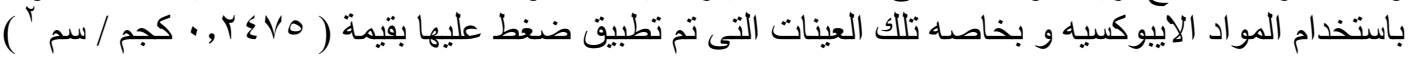

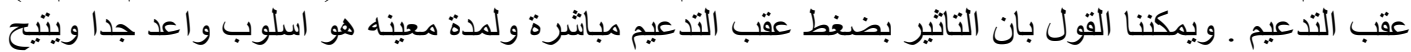

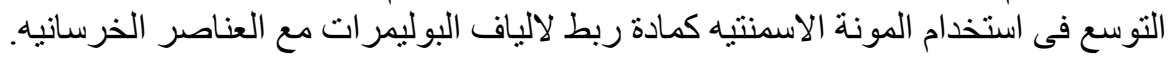

